\title{
Perancangan maximum power point tracking dengan algoritma incremental conductance untuk PLTS $100 \mathrm{Wp}$
}

\author{
Abdullah Assegaf ${ }^{1 *}$, Dedi Aming ${ }^{2}$, Febri Alvianto ${ }^{3}$ \\ 1,2,3 Jurusan Teknik Elektro, Politeknik Negeri Bandung \\ Jl. Gegerkalong Hilir, Ciwaruga, Kec. Parongpong, Kabupaten Bandung Barat, Jawa Barat, Indonesia \\ ${ }^{1 *}$ abdullah.assegaf@polban.ac.id, ${ }^{2}$ deam2k@yahoo.com, ${ }^{3}$ alvianto.febri@gmail.com
}

\begin{abstract}
ABSTRAK
Efisiensi konversi energi yang rendah menjadi masalah utama pada pembangkit listrik tenaga surya (PLTS). Makalah ini membahas tentang implementasi metode maximum power point tracking (MPPT) dengan algoritma incremental conductance (IC) pada sistem panel surya dengan kapasitas 100 Wattpeak (Wp) yang bertujuan untuk mendapatkan daya keluaran yang paling optimal dari panel surya. Sistem dibangun dengan menggunakan konverter DC/DC buck-boost dan mikrokontroler sebagai pengolah algoritma MPPT serta pusat kendali sistem. Mikrokontroler akan mengontrol duty cycle dari konverter buck-boost dan memastikan bahwa panel surya selalu beroperasi pada kondisi titik daya maksimum dengan menggunakan algoritma IC. Hasil pengujian menunjukkan bahwa penggunaan metode MPPT dengan algoritma IC pada sistem panel surya $100 \mathrm{Wp}$ dapat memaksimalkan daya keluaran dari panel surya sebesar 56\%-94\% dibandingkan dengan penggunaan panel surya secara langsung tanpa menggunakan MPPT.
\end{abstract}

Kata kunci: MPPT, incremental conductance, buck-boost converter

\section{ABSTRACT}

Low energy conversion efficiency is a major problem in solar power plants (PLTS). This paper discusses the implementation of the maximum power point tracking (MPPT) method with an incremental conductance (IC) algorithm in a solar panel system with a capacity of 100 Wattpeak (Wp) which aims to obtain the most optimal output power from solar panels. The system is built using a buck-boost DC/DC converter and a microcontroller as an MPPT algorithm processor and system control center. The microcontroller will control the duty cycle of the buck-boost converter and ensure that the solar panels always operate at maximum power point conditions using the IC algorithm. The test results show that the use of the MPPT method with the IC algorithm on a 100 Wp solar panel system can maximize the output power of the solar panels by 56\%-94\% compared to the use of solar panels directly without using MPPT.

Keywords: MPPT, incremental conductance, buck-boost converter

\section{PENDAHULUAN}

Energi matahari merupakan salah satu sumber energi baru terbarukan yang keberadaannya dapat dimanfaatkan sebagai sumber untuk penyediaan tenaga listrik. Proses konversi energi matahari menjadi energi listrik dapat dilakukan dengan memanfaatkan panel surya. Namun, pada proses pembangkitan tenaga listrik menggunakan panel surya masih terdapat kelemahan, salah satunya adalah efisiensi konversi energi yang sangat rendah yaitu sekitar 8\%-18\% [1]. Efisiensi panel surya dipengaruhi oleh banyak faktor seperti, suhu, insolasi, karakteristik spektral sinar matahari, tingkat kekotoran permukaan panel surya, dan bayangan [2]-[4]. Perubahan isolasi pada panel sangat mempengaruhi daya keluaran dari panel surya, sehingga jumlah energi yang dihasilkan oleh susunan panel surya sangat berkaitan dengan kondisi lingkungan dan operasionalnya.

Dalam mengatasi permasalahan efisiensi panel surya yang rendah, dikembangkan beberapa metode, salah satunya yang banyak diimplementasikan saat ini adalah maximum power point tracking (MPPT). MPPT adalah metode yang berfokus pada pelacakan titik daya maksimum yang mampu dihasilkan oleh sistem panel surya yang terdiri dari rangkaian elektronika daya, kontroler, dan algoritma pencarian yang berfungsi untuk mempertahankan panel surya supaya selalu bekerja pada titik tersebut [1], [5]. Pelacakan maximum power point (MPP) harus dilakukan secara terus menerus 
karena nilai MPP akan selalu berubah-ubah mengikuti perubahan kondisi lingkungan yang terjadi. Banyak algoritma pencarian yang telah dikembangkan sampai saat ini, namun yang sering digunakan adalah algoritma constant voltage, perturb and observe ( $\mathrm{P} \& \mathrm{O})$, dan incremental conductance (IC) karena aspek kesederhanaan dan kemudahan dalam implementasinya. Metode constant voltage dapat digunakan karena memiliki karakteristik sederhana dan murah, seperti yang telah disimulasikan pada penelitian [6] dengan beban panel surya berupa motor DC. Algoritma P\&O masih memiliki kelemahan, yaitu ketika MPP sudah tercapai daya keluaran akan berisolasi disekitar nilai maksimum yang dapat mengakibatkan hilangnya daya dalam sistem panel surya. Selain itu, ada potensi algoritma ini terjadi kegagalan ketika kondisi atmosfir berubah dengan cepat [7]. Penelitian yang dilakukan oleh [8] dimana telah dibuat sistem MPPT menggunakan algoritma P\&O dan DC/DC buck converter menunjukkan penggunaan algoritma $\mathrm{P} \& \mathrm{O}$ pada sistem panel surya hanya mampu menjejak daya maksimal hingga $20 \%$ dari pembebanan secara langsung. Algoritma IC dikembangkan untuk mengatasi permasalahan pada algoritma constant voltage dan $\mathrm{P} \& \mathrm{O}[9]$.

Tujuan dari penelitian ini adalah untuk merancang metode MPPT pada pembangkit listrik tenaga surya (PLTS) $100 \mathrm{Wp}$ dengan algoritma IC. Metode MPPT dengan algoritma IC dirancang untuk mendapatkan daya keluaran yang paling optimal dari panel surya serta mengetahui kinerja sistem MPPT menggunakan algoritma Incremental Conductance. Berbeda dengan beberapa penelitian sebelumnya, pada penelitian ini akan dibangun sistem MPPT menggunakan algoritma IC dengan konverter jenis buck-boost yang mampu menaikkan atau menurunkan tegangan keluaran. Simulasi berbasis MATLAB/Simulink dilakukan sebagai metode analisis dan pengujian sistem yang dirancang.

\section{METODE PENELITIAN}

Pada bagian ini akan dibahas mengenai perancangan sistem yang terdiri dari buck-boost converter, algoritma IC, serta implementasinya pada MATLAB/Simulink.

\subsection{Perancangan Buck-Boost Converter}

Buck-boost converter merupakan salah satu jenis konverter DC/DC yang dapat menghasilkan tegangan yang lebih tinggi atau lebih rendah dari tegangan sumbernya [9], [10]. Perencanaan dan perancangan rangkaian konverter buck-boost ditentukan berdasarkan dari kriteria desain sistem MPPT nya, yaitu dengan merujuk pada spesifikasi panel surya yang digunakan seperti yang ditunjukkan pada Tabel 1. Adapun rangkaian buck-boost converter dapat dilihat pada Gambar 1.

Tabel 1. Spesifikasi panel surya yang digunakan

\begin{tabular}{|l|c|l|c|}
\hline \multicolumn{1}{|c|}{ Spesifikasi } & Nilai & \multicolumn{1}{c|}{ Spesifikasi } & Nilai \\
\hline Jenis panel surya & Mono-Si & Arus hubung singkat (Isc) & $5,9 \mathrm{~A}$ \\
\hline Merek/pabrikan & GH Solar & Normal operating cell temp. & $47 \pm 2^{\circ} \mathrm{C}$ \\
\hline Model & GH100M-18 & Tegangan sistem maksimum & $1000 \mathrm{VDC}$ \\
\hline Daya maksimum $(\mathrm{Pm})$ & $100 \mathrm{WP}$ & Rating fuse maksimum & $10 \mathrm{~A}$ \\
\hline Toleransi & $\pm 3 \%$ & Temperatur operasi & -40 to $+85^{\circ} \mathrm{C}$ \\
\hline $\begin{array}{l}\text { Tegangan saat daya maksimum } \\
\text { (Vmp) }\end{array}$ & $18 \mathrm{~V}$ & Kelas aplikasi & Kelas A \\
\hline Arus saat daya maksimum (Imp) & $5,56 \mathrm{~A}$ & Berat & $7,8 \mathrm{~kg}$ \\
\hline Tegangan rangkaian terbuka (Voc) & $22,6 \mathrm{~V}$ & Dimensi & $\begin{array}{c}1006 \times 70 \times 30 \\
\mathrm{~mm}\end{array}$ \\
\hline
\end{tabular}

Tabel 2. Parameter buck-boost converter

\begin{tabular}{|l|c|}
\hline \multicolumn{1}{|c|}{ Parameter } & Nilai \\
\hline Tegangan masukan maksimum (Vs maks) & $18 \mathrm{~V}$ \\
\hline Tegangan masukan minimum (Vs min) & $9 \mathrm{~V}$ \\
\hline Tegangan keluaran (Vout) & $14 \mathrm{~V}$ \\
\hline Arus keluaran (Iout) & $7 \mathrm{~A}$ \\
\hline Frekuensi switching $(f)$ & $20 \mathrm{kHz}$ \\
\hline Ripple tegangan $(\Delta \mathrm{Vo})$ & $1 \%$ \\
\hline
\end{tabular}




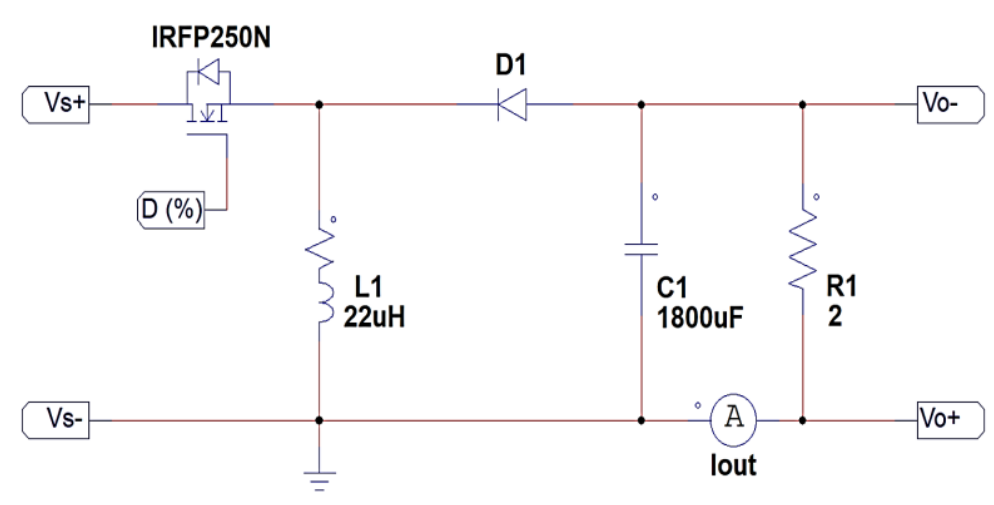

Gambar 1. Rangkaian buck-boost converter

Tabel 2 menunjukkan parameter-parameter dari buck-boost converter yang dibangun pada penelitian ini. Berdasarkan parameter yang ditunjukkan, maka dapat dilakukan perhitungan untuk menentukan nilai dari komponen-komponen yang digunakan pada rangkaian buck-boost converter. Perhitungan yang dilakukan pertama kali adalah dengan menentukan nilai duty cycle supaya tegangan keluaran dari konverter sesuai dengan parameter yang telah ditentukan. Nilai duty cycle juga dibutuhkan untuk menentukan nilai induktor minimum dan nilai kapasitor pada rangkaian. Persamaan tegangan keluaran buck-boost converter adalah sebagai berikut.

$$
V o=-V s\left(\frac{D}{1-D}\right)
$$

dengan $V o$ adalah tegangan keluaran, $V s$ adalah tegangan masukan, dan $D$ adalah duty cycle. Mengacu pada (1) nilai duty cycle dapat dihitung dengan memasukkan parameter tegangan keluaran yang diinginkan dan tegangan masukan. Persamaan (2) merupakan persamaan untuk menentukan nilai resistansi beban $R$ sehingga didapatkan arus keluaran $I o$ sesuai dengan parameter yang ditentukan.

$$
R=\frac{V o}{I o}
$$

Konverter yang direncanakan pada penelitian ini akan dioperasikan dalam mode continous current mode (CCM), sehingga besarnya induktansi minimum pada rangkaian dapat dihitung menggunakan persamaan (3).

$$
\operatorname{Lmin}=\frac{(1-D)^{2} R}{2 f}
$$

dengan Lmin adalah nilai induktansi minimum dan $f$ adalah frekuensi switching. Tegangan keluaran dari konverter kemudian difilter dengan kapasitor untuk mengurangi ripple tegangan. Besarnya nilai kapasitansi minimum $(C)$ yang digunakan pada rangkaian buck-boost converter dapat dihitung dengan memperhatikan hubungan faktor ripple yang dinyatakan pada persamaan (4).

$$
C=\frac{\operatorname{Vo} D}{\operatorname{R} \Delta \operatorname{Vo} f}
$$

Sebelum menghitung nilai kapasitor terlebih dahulu dihitung ripple tegangan $(\triangle \mathrm{Vo})$ yang diinginkan menggunakan persamaan (5) sesuai dengan parameter pada Tabel 2.

$$
\Delta \mathrm{Vo}_{\mathrm{o}}=1 \% \mathrm{xo}
$$

\subsection{Perancangan Algoritma IC}

Algoritma IC merupakan algoritma yang dikembangkan berdasarkan gradien kurva karakteristik $\mathrm{P}-\mathrm{V}$ dari sel surya yang mana nilai MPP akan tercapai apabila $\mathrm{dP} / \mathrm{dV}=0$ [1], [12]-[13]. Besaran tegangan dan arus keluaran dari panel surya merupakan parameter penting yang dibutuhkan algoritma IC untuk mengetahui MPP dari panel surya. Nilai MPP dapat dihitung dengan memperhatikan hubungan antara $\mathrm{d} / \mathrm{dV}$ (incremental conductance) dan $\mathrm{I} / \mathrm{V}$ (instantaneous conductance) seperti ditunjukkan pada persamaan berikut [1]. 


$$
\begin{gathered}
\frac{d P}{d V}=\frac{d(V \cdot I)}{d V}=I \frac{d V}{d V}+V \frac{d I}{d V} \\
\frac{d P}{d V}=I+V \frac{d I}{d V} \\
\frac{d I}{d V}=-\frac{1}{V}
\end{gathered}
$$

Mengacu pada (8) jika nilai dI/dV lebih besar dari -I/V, artinya titik operasi berada disebelah kiri MPP sehingga Vref perlu ditambah. Sebaliknya apabila nilai dI/dV lebih kecil dari -I/V, artinya titik operasi berada disebelah kanan MPP sehingga Vref perlu dikurangi. Proses ini akan terus diulangi sampai nilai $\mathrm{d} / \mathrm{dV}$ sama dengan $-\mathrm{I} / \mathrm{V}$, yang berarti Vref = Vmpp. Pengamatan perubahan nilai IC dan instantaneous conductance dilakukan secara terus menerus berdasarkan dari hasil pembacaan sensor arus dan sensor tegangan yang dilakukan secara berkala. Nilai tegangan dan arus setelah terjadi perubahan duty cycle akan diperbaharui untuk dijadikan referensi pada looping program selanjutnya. Gambar 2 menunjukkan kurva P-V panel surya dan hubungannya dengan algoritma IC, sedangkan Gambar 3 merupakan diagram alir dari proses pelacakan nilai MPP menggunakan algoritma IC.

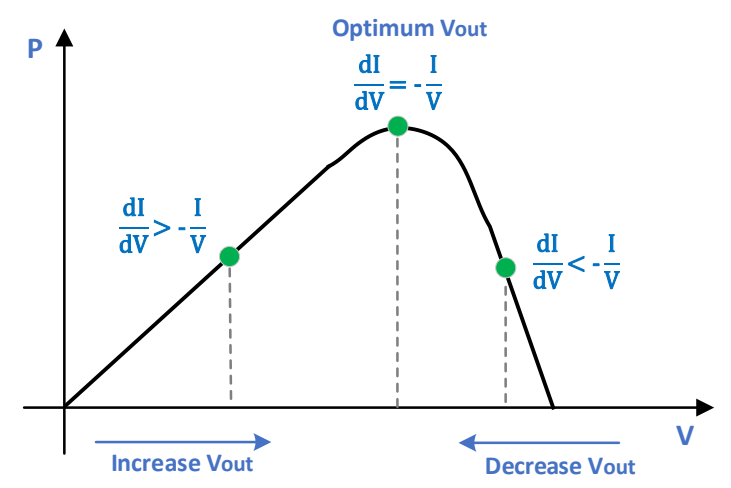

Gambar 2. Kurva P-V dan algoritma IC

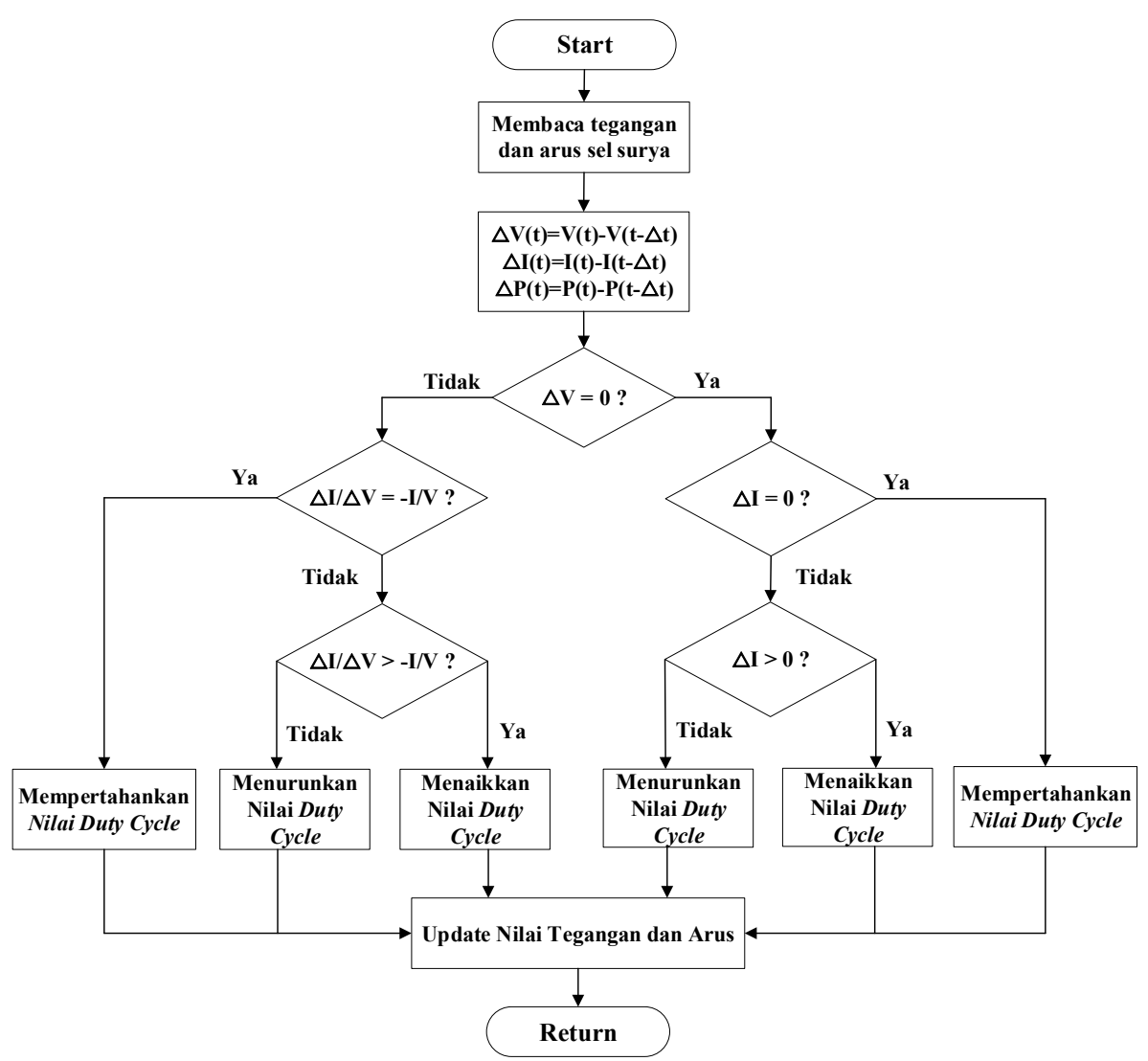

Gambar 3. Diagram alir algoritma IC 


\subsection{Pemodelan dan Simulasi Sistem}

Setelah dilakukan perancangan perangkat keras dan perancangan perangkat lunak, langkah selanjutnya adalah melakukan pemodelan dan simulasi sistem secara keseluruhan dengan menggunakan aplikasi MATLAB/Simulink. Hal ini dilakukan untuk memastikan bahwa sistem yang dibuat dapat bekerja dan sudah sesuai dengan perencanaan awal. Gambar 4 menunjukkan rangkaian pemodelan sistem MPPT algoritma IC pada MATLAB/Simulink.

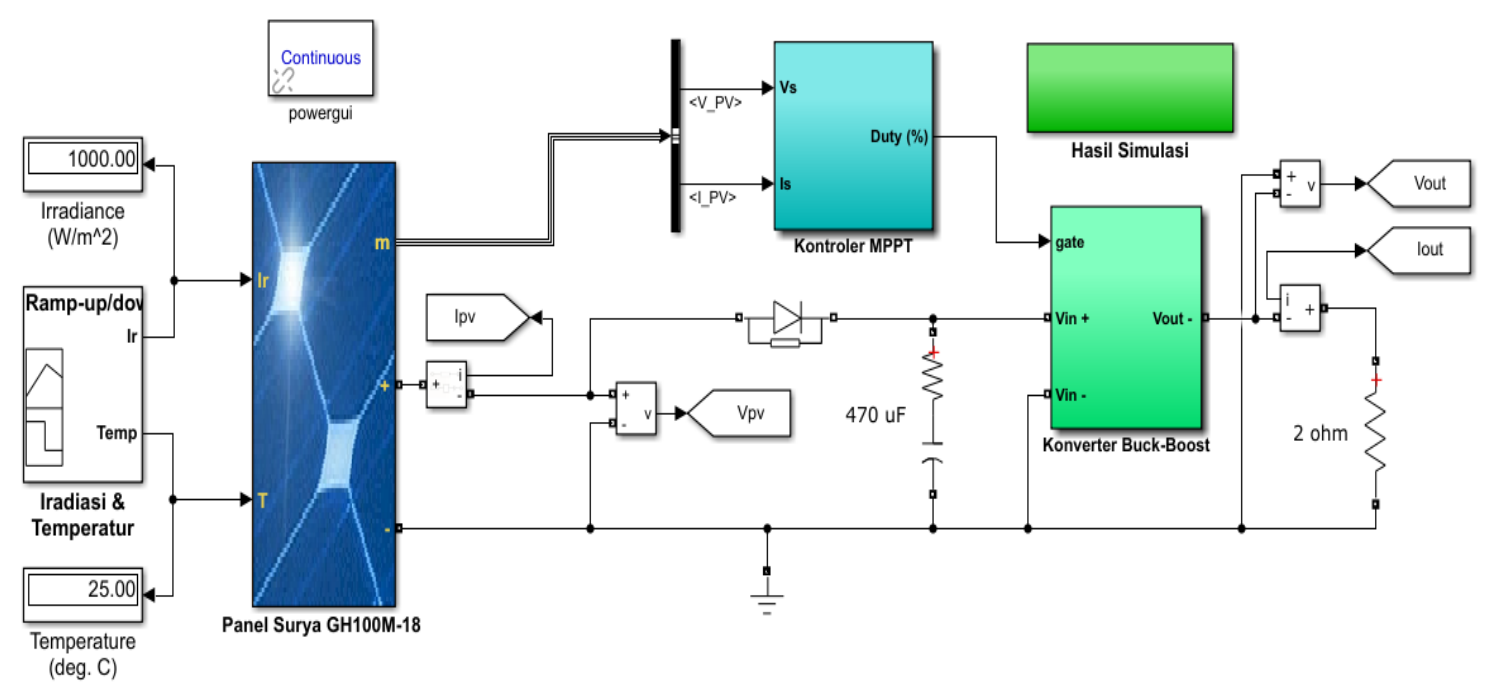

Gambar 4. Pemodelan sistem MPPT dengan algoritma IC

Rangkaian pemodelan terdiri dari modul surya, subsistem kontroler MPPT, subsistem buck-boost converter, dan beban resistif. Sebelum simulasi dijalankan terlebih dahulu parameter modul surya di MATLAB disesuaikan dengan spesifikasi panel surya yang tertera pada Tabel 1. Simulasi dilakukan dengan memberikan masukan berupa variabel iradiasi dan temperatur ke panel surya. Besarnya nilai iradiasi diubah-ubah dalam dua kondisi, yaitu saat iradiasi konstan sebesar $1000 \mathrm{~W} / \mathrm{m}^{2}$ dan ketika iradiasi fluktuatif, sedangkan besarnya nilai temperatur ditetapkan dalam kondisi sebesar $25^{\circ} \mathrm{C}$.

\section{HASIL DAN PEMBAHASAN}

Untuk mengetahui karakteristik dan unjuk kerja dari sistem MPPT dengan algoritma IC yang diimplementasikan pada panel surya monocrystalline $100 \mathrm{Wp}$, maka perlu dilakukan pengujian sistem. Pengujian dilakukan dengan dua tahap, yaitu pengujian sistem panel surya ketika tanpa menggunakan MPPT IC dan pengujian sistem panel surya dengan menggunakan MPPT IC. Gambar 5 dan Gambar 6 menunjukkan hasil pengujian pada sistem panel surya tanpa dan dengan MPPT IC.
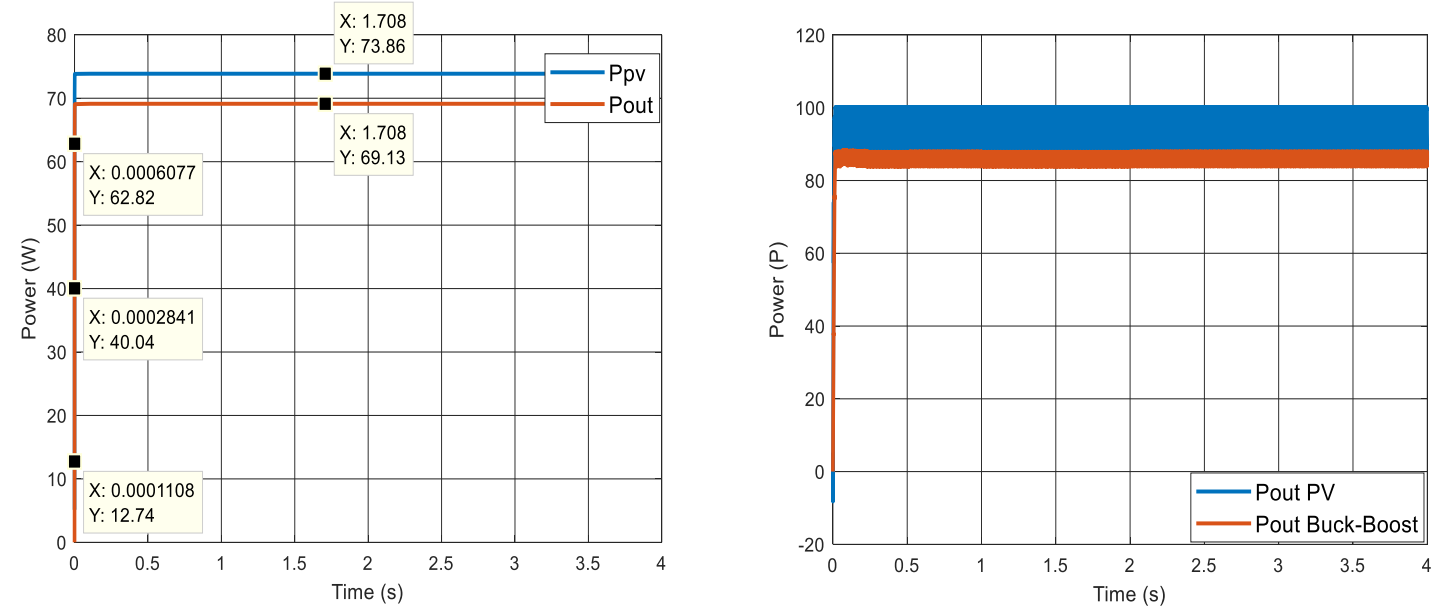

Gambar 5. Hasil plot daya keluaran sistem saat pengujian dengan iradiasi konstan $1000 \mathrm{~W} / \mathrm{m}^{2} \operatorname{tanpa}$ MPPT IC (kiri) dan dengan MPPT IC (kanan) 

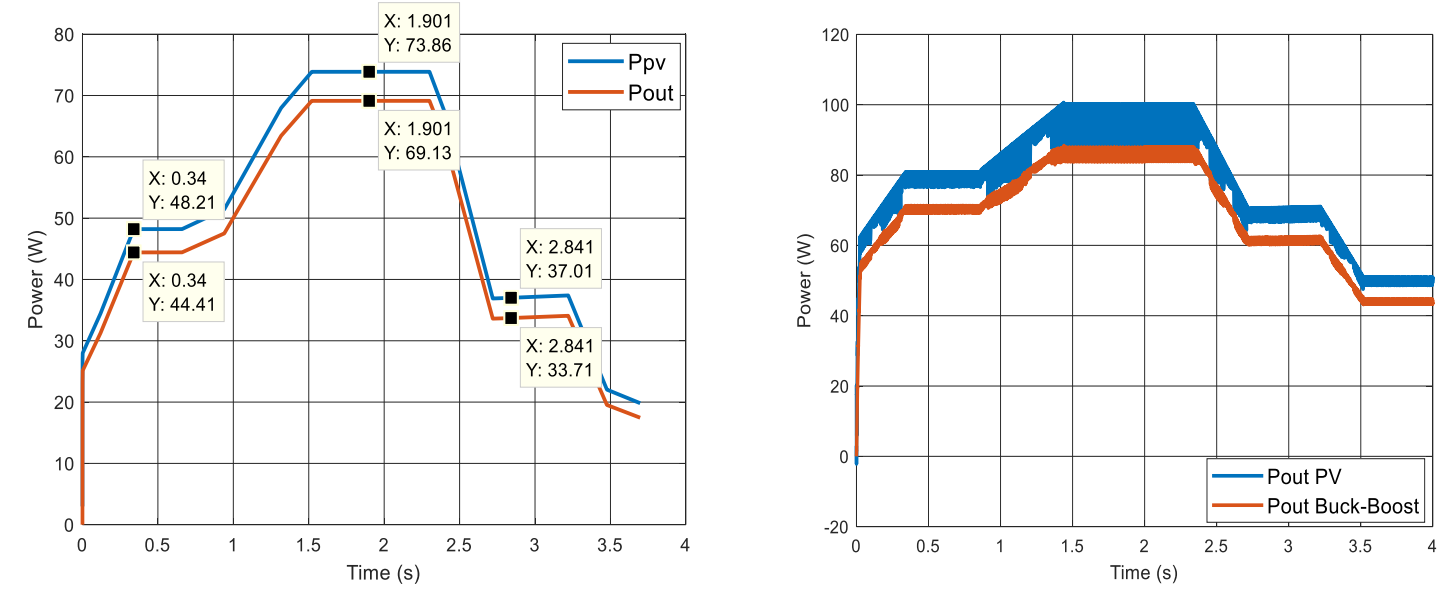

Gambar 6. Hasil plot daya keluaran sistem saat pengujian dengan iradiasi fluktuatif tanpa MPPT IC (kiri) dan dengan MPPT IC (kanan)

Hasil pengujian menunjukkan daya keluaran dari sistem panel surya tanpa menggunakan MPPT masih jauh dari MPP nya. Hal ini dikarenakan tegangan dan arus keluaran panel surya tidak berada pada nilai Vmpp dan Impp. Pada pengujian dengan MPPT IC menunjukkan daya keluaran dari sistem panel surya sudah mendekati nilai MPP nya. Hal ini dikarenakan MPPT IC memaksa tegangan dan arus keluaran panel surya untuk selalu mendekati nilai Vmpp dan Impp. Berdasarkan hasil pengujian, sistem MPPT algoritma IC terbukti mampu mendeteksi adanya perubahan nilai MPP pada setiap terjadi perubahan iradiasi. MPPT berhasil menjaga panel surya supaya selalu beroperasi mendekati kondisi MPP nya sehingga didapatkan daya keluaran yang maksimal dari setiap kondisi operasi.

Tabel 2. Hasil pengujian sistem dengan iradiasi konstan $1000 \mathrm{~W} / \mathrm{m}^{2}$

\begin{tabular}{|l|c|c|c|c|c|c|}
\hline \multicolumn{1}{|c|}{ Kondisi } & $\begin{array}{c}\text { Vpv } \\
\text { (V) }\end{array}$ & $\begin{array}{c}\text { Ipv } \\
(\mathbf{A})\end{array}$ & $\begin{array}{c}\text { Ppv } \\
\text { (W) }\end{array}$ & $\begin{array}{c}\text { Vout } \\
\text { (V) }\end{array}$ & $\begin{array}{c}\text { Iout } \\
(\mathbf{A})\end{array}$ & $\begin{array}{c}\text { Pout } \\
(\mathbf{W})\end{array}$ \\
\hline Tanpa MPPT & 10,54 & 5,89 & 61,97 & 9,73 & 4,87 & 54,78 \\
\hline Dengan MPPT & 17,81 & 5,48 & 97,40 & 13,11 & 6,55 & 85,95 \\
\hline
\end{tabular}

Tabel 3. Hasil pengujian sistem dengan iradiasi fluktuatif

\begin{tabular}{|l|c|c|c|c|c|c|}
\hline \multicolumn{1}{|c|}{ Kondisi } & $\begin{array}{c}\text { Vpv } \\
(\mathbf{V})\end{array}$ & $\begin{array}{c}\text { Ipv } \\
(\mathbf{A})\end{array}$ & $\begin{array}{c}\text { Ppv } \\
\text { (W) }\end{array}$ & $\begin{array}{c}\text { Vout } \\
(\mathbf{V})\end{array}$ & $\begin{array}{c}\text { Iout } \\
(\mathbf{A})\end{array}$ & $\begin{array}{c}\text { Pout } \\
(\mathbf{W})\end{array}$ \\
\hline Tanpa MPPT & 8,54 & 4,34 & 39,66 & 7,73 & 3,87 & 35,46 \\
\hline Dengan MPPT & 17,98 & 4,37 & 78,44 & 11,66 & 5,83 & 68,88 \\
\hline
\end{tabular}

Hasil pengujian dengan iradiasi konstan $1000 \mathrm{~W} / \mathrm{m}^{2}$ pada Tabel 2 menunjukkan sistem panel surya tanpa menggunakan MPPT hanya mampu menghasilkan daya rata-rata sebesar $54,78 \mathrm{~W}$, sedangkan sistem panel surya dengan menggunakan MPPT mampu menghasilkan daya rata-rata sebesar 85,95 W. Terdapat peningkatan daya keluaran dari sistem panel surya sebesar 31,17 W atau jika dipersentasekan terdapat kenaikan sebesar 56\% dibandingkan dengan sistem PV tanpa menggunakan MPPT. Dari hasil pengujian dengan iradiasi fluktuatif yang ditunjukkan pada Tabel 3, diketahui sistem panel surya tanpa menggunakan MPPT hanya mampu menghasilkan daya rata-rata sebesar 35,46 W, sedangkan sistem panel surya dengan menggunakan MPPT mampu menghasilkan daya rata-rata sebesar $68,88 \mathrm{~W}$. Terdapat peningkatan daya keluaran dari sistem panel surya sebesar $33,42 \mathrm{~W}$ atau jika dipersentasekan terdapat kenaikan sebesar 94\% dibandingkan sistem PV tanpa menggunakan MPPT IC.

\section{KESIMPULAN}

Sistem MPPT dengan algoritma IC untuk panel surya $100 \mathrm{Wp}$ telah berhasil dirancang dan disimulasikan. Hasil simulasi dan pengujian sistem MPPT algoritma IC menggunakan buck-boost converter dengan beban resistif $2 \mathrm{Ohm}$ menunjukkan bahwa sistem MPPT dengan algoritma IC mampu menjaga panel surya supaya selalu beroperasi mendekati kondisi MPP nya sehingga dapat 
memaksimalkan daya keluaran dari panel surya antara 56\% sampai $94 \%$. Untuk penelitian selanjutnya dapat dikembangkan dengan menambahkan jumlah panel surya yang terpasang, sehingga dapat diketahui pengaruh gangguan bayangan pada beberapa panel surya yang terpasang terhadap hasil pelacakan MPP oleh algoritma IC atau dengan mengubah jenis konverter DC-DC yang digunakan pada sistem.

\section{REFERENSI}

[1] R. I. Putri, S. Wibowo, and M. Rifa'i, "Maximum Power Point Tracking for Photovoltaic Using Incremental Conductance Method," Energy Procedia, vol. 68, pp. 22-30, 2015.

[2] M. Boxwell, Solar Electricity Handbook 2012 Edition, Sixth. Greenstream Publishing, 2012.

[3] A. S. Jaibhai and A. S. Patil, "Simulation of Incremental Conductance Based Solar MPPT System," Int. J. Ind. Electron. Electr. Eng., vol. 4, no. 9, pp. 51-55, 2016.

[4] A. Safari and S. Mekhilef, "Simulation and Hardware Implementation of Incremental Conductance MPPT With Direct Control Method Using Cuk Converter," IEEE Trans. Ind. Electron., vol. 58, no. 4, pp. 11541161, 2011.

[5] M. I. Fadriantama, "Analisis Perbandingan Kinerja Algoritme Perturb and Observe (P\&O) dan Incremental Conductance (IC) Pada Sistem Kendali Maximum Power Point Tracker (MPPT) Untuk Sistem Photovoltaic (PV) Paralel,” Skripsi Universitas Islam Indonesia, Yogyakarta, 2018.

[6] A. W. Leedy, L. Guo, and K. A. Aganah, "A constant voltage MPPT method for a solar powered boost converter with DC motor load," in 2012 Proceedings of IEEE Southeastcon, 2012, pp. 1-6.

[7] Y. Santosa and A. Assegaf, "Pemodelan dan Simulasi MPPT P\&O PV Berbasis PSIM dan MATLAB/SIMULINK," Pros. Semin. Nas. FORUM Res. Sci. Technol., 2015.

[8] H. Fathuddin, "Rancang Bangun Sistem Pengisian Baterai 12V/5Ah Dengan Panel Surya Monocrystalline Dan Metode MPPT Perturb \& Observe Berbasis Atmega 16," Tugas Akhir Politeknik Negeri Bandung, 2017.

[9] H. Shahid, M. Kamran, Z. Mehmood, M. Y. Saleem, M. Mudassar, and K. Haider, "Implementation of the novel temperature controller and incremental conductance MPPT algorithm for indoor photovoltaic system, " Solar Energy, vol. 163, pp. 235-242, 2018.

[10] M. H. Rashid, Power Electronics Handbook Devices, Circuits, and Applications, Third. Elsevier Inc, 2011.

[11] D. W. Hart, Power Electronics. McGraw-Hill, 2011.

[12] S. Khadidja, M. Mountassar, and B. M'Hamed, "Comparative Study of Incremental Conductance and Perturb \& Observe MPPT Methods for Photovoltaic System," Int. Conf. Green Energy Convers. Syst. GECS 2017, 2017.

[13] S. Utami, S. Saodah, and A. Pudin, "Penggunaan Algoritma Incremental Conductance pada MPPT dengan Buck Converter untuk Pengujian Indoor dan Outdoor," ELKOMIKA J. Tek. Energi Elektr. Tek. Telekomun. Tek. Elektron., vol. 6, no. 1, pp. 97-109, 2018. 
